\title{
Flavonol Acylglycosides from Flower of Albizia julibrissin and Their Inhibitory Effects on Lipid Accumulation in 3T3-L1 Cells
}

\author{
Tadahiro Yahagi, Akihiro Daikonya, ${ }^{\dagger}$ and Susumu Kitanaka* \\ School of Pharmacy, Nihon University; 7-7-1 Narashinodai, Funabashi, Chiba 274-8555, Japan. \\ Received September 28, 2011; accepted October 25, 2011
}

Obesity is a serious health problem worldwide. We investigated the anti-obesity effect of the flower of Albizia julibrissin Durazz. (Leguminosae). A 90\% EtOH extract of the flower inhibited adipogenesis in 3T3L1 preadipocytes, as well as the activity of glycerol-3-phosphate dehydrogenase (GPDH) activity. New flavonol acylglycosides (1-4) and eighteen known compounds (5-22) were isolated by bioassay-directed fractionation. These new glycosides were elucidated to be $3^{\prime \prime}-(E)$-p-coumaroylquercitrin $(1), 3^{\prime \prime}$-(E)-feruloylquercitrin $(2), 3 "-(E)$-cinnamoylquercitrin (3), and $2^{\prime \prime}-(E)$-cinnamoylquercitrin (4) on the basis of spectroscopic and chemical analysis. These compounds inhibited adipogenesis in 3T3-L1 preadipocytes. In particular, 2 exhibited potent inhibitory effects on triglyceride accumulation. Furthermore, GPDH activity was inhibited by 2. Additionally, 2 inhibited glucose uptake in 3T3-L1 adipocytes. These results indicate that the $90 \% \mathrm{EtOH}$ extract and compounds isolated from the flower of $A$. julibrissin inhibit adipogenesis in 3T3-L1 preadipocytes and may have anti-obesity effect through the inhibition of preadipocyte differentiation.

Key words Albizia julibrissin; flavonoid acylglycoside; 3T3-L1 cell; obesity; lipid accumulation

Albizia julibrissin Durazz., belongs to the Leguminosae family and is native to Japan, China, and Korea. The flowers of this plant have been used in traditional medicine for the treatment of insomnia, amnesia, sore throat, and contusions. ${ }^{1)}$ Phytochemical investigations of the flower of A. julibrissin resulted in the isolation of flavonoids, ${ }^{2,3)}$ sterols, ${ }^{4)}$ and ceramides. ${ }^{5)}$

Obesity is one of the leading metabolic diseases worldwide $^{6)}$ and it is closely associated with coronary heart disease, hypertension, type 2 diabetes mellitus, cancer, respiratory complications, and osteoarthritis. ${ }^{7)}$ Obesity is a condition in which adipocytes accumulate a large amount of fat and become enlarged. This condition is characterized at the cellular level by an increase in the number and size of adipocytes that differentiate from 3T3-L1 preadipocytes in adipose tissue. ${ }^{8)}$ The cytosolic enzyme glycerol-3-phosphate dehydrogenase (GPDH) appears to have an important role in the conversion of glycerol into triglyceride (TG). ${ }^{9)}$ TG is synthesized from glucose and fatty acid that is incorporated by glucose transporter 4 and fatty acid transporter CD36 in 3T3-L1 preadipocytes. $^{10,11)}$ Cultured 3T3-L1 adipocytes show many properties that are similar to those of normal adipocytes. Thus, this cell line is a suitable model system for obesityrelated research. ${ }^{12-14)}$ Herbal extracts from plants, such as Blumea balsamifera ${ }^{15)}$ Ginkgo biloba ${ }^{16)}$ Wasabia japonica, ${ }^{17}$ and Zizyphus jujube, ${ }^{18)}$ have been found to possess anti-obesity effects. Furthermore, natural products also have been reported as a subject for an obesity study in 3T3-L1 cells. Previously, quercetin, ${ }^{19,20)}$ berberine, ${ }^{21)}$ ginsenosides, ${ }^{22)}$ and curcumin, ${ }^{23)}$ on lipid accumulation in 3T3-L1 adipocytes was investigated. Consequently, crude drugs and natural products with similar properties would help to solve obesity problems worldwide.

During the studies on medicinal herbal extracts that influences 3T3-L1 adipocytes, the 90\% aqueous ethanol extract of the flower of $A$. julibrissin was observed to inhibit intracellular TG accumulation in 3T3-L1 adipocytes. Four new flavonol

${ }^{\dagger}$ Present address: Research Center for Medicinal Plant Resources National Institute of Biomedical Innovation (NIBIO). acylglycosides $\mathbf{1}-\mathbf{4}$, namely $3^{\prime \prime}-(E)-p$-coumaroylquercitrin (1), $3 "$-(E)-feruloylquercitrin (2), 3"-(E)-cinnamoylquercitrin (3), and $2^{\prime \prime}-(E)$-cinnamoylquercitrin (4), and eighteen known from the flower of $A$. julibrissin were isolated by bioassay-directed fractionation. Herein, we describe the elucidation of these structures and evaluate their biological properties.

\section{Results and Discussion}

The flowers of $A$. julibrissin were extracted with $90 \%$ aqueous ethanol (AJ ext.). The cytotoxicity of AJ ext. at concentrations $(10,30,100 \mu \mathrm{g} / \mathrm{mL})$ was evaluated by the 3-(4,5-dimethylthiazol-2-yl)-2,5-diphenyltetrazolium bromide (MTT) assay in 3T3-L1 cells. The results showed that AJ ext. induced cytotoxicity of 3T3-L1 cells at concentration of $30 \mu \mathrm{g} /$ $\mathrm{mL}$ (cell viability: $76.8 \%$ ). Thus, we treated with $10 \mu \mathrm{g} / \mathrm{mL}$ AJ ext. (cell viability: 97.4\%) in 3T3-L1 cells. Eight days after induction differentiation, the cellular TG content and GPDH enzyme activity were measured. TG and GPDH measurements were corrected for the amount of DNA. Treatment with $10 \mu \mathrm{g} /$ $\mathrm{mL}$ AJ ext. inhibited the TG accumulation (67.4\%) and GPDH activity $(60.2 \%)$ as compared to the untreated control.

The AJ ext. was suspended in $\mathrm{H}_{2} \mathrm{O}$ and partitioned with $n$-hexane, $\mathrm{CHCl}_{3}$, EtOAc, and $n$ - $\mathrm{BuOH}$, successively. TG assay results indicated that the fractions had inhibitory effects on intracellular TG accumulation (data not shown). Among these fractions, the EtOAc-soluble fraction inhibited $73.2 \%$ of TG accumulation at $30 \mu \mathrm{g} / \mathrm{mL}$ without significant cytotoxicity. Therefore, the EtOAc-soluble fraction was subjected to normal-phase and reverse-phase column chromatography and finally to HPLC to yield four new flavonoid glycosides (1-4) together with eighteen known compounds (5-22) by bioassay-directed fractionation.

$3^{\prime \prime}-(E)-p$-Coumaroylquercitrin (1) was isolated as a yellow powder having a negative optical rotation $\left([\alpha]_{\mathrm{D}}^{25}-146^{\circ}\right)$, and its molecular formula was determined to be $\mathrm{C}_{30} \mathrm{H}_{26} \mathrm{O}_{13}$ by negative high resolution (HR)-FAB-MS. The UV spectrum of 1 showed absorptions at 267 and $315 \mathrm{~nm}$, and its IR spectrum showed characteristic absorption bands for a hydroxy group $\left(3378 \mathrm{~cm}^{-1}\right)$, a conjugated carbonyl group $\left(1654 \mathrm{~cm}^{-1}\right)$, and a 
Table 1. ${ }^{1} \mathrm{H}-\mathrm{NMR}(500 \mathrm{MHz})$ Data for Compounds $\mathbf{1}-\mathbf{4}\left(\mathrm{DMSO}-d_{6}\right.$ with TMS as the Internal Standard)

\begin{tabular}{|c|c|c|c|c|}
\hline Position & 1 & 2 & 3 & 4 \\
\hline \multicolumn{5}{|l|}{ Aglycone moiety } \\
\hline 6 & $6.23(1 \mathrm{H}, \mathrm{d}, J=2.0)$ & $6.24(1 \mathrm{H}, \mathrm{d}, J=2.0)$ & $6.22(1 \mathrm{H}, \mathrm{d}, J=2.0)$ & $6.22(1 \mathrm{H}, \mathrm{d}, J=2.0)$ \\
\hline 8 & $6.42(1 \mathrm{H}, \mathrm{d}, J=2.0)$ & $6.45(1 \mathrm{H}, \mathrm{d}, J=2.0)$ & $6.41(1 \mathrm{H}, \mathrm{d}, J=2.0)$ & $6.42(1 \mathrm{H}, \mathrm{d}, J=2.0)$ \\
\hline $2^{\prime}$ & $7.31(1 \mathrm{H}, \mathrm{d}, J=2.1)$ & $7.32(1 \mathrm{H}, \mathrm{d}, J=2.0)$ & $7.30(1 \mathrm{H}, \mathrm{d}, J=2.0)$ & $7.35(1 \mathrm{H}, \mathrm{d}, J=2.3)$ \\
\hline $5^{\prime}$ & $6.89(1 \mathrm{H}, \mathrm{d}, J=8.3)$ & $6.93(1 \mathrm{H}, \mathrm{d}, J=8.8)$ & $6.90(1 \mathrm{H}, \mathrm{d}, J=8.3)$ & $6.90(1 \mathrm{H}, \mathrm{d}, J=8.3)$ \\
\hline $6^{\prime}$ & $7.33(1 \mathrm{H}, \mathrm{dd}, J=8.3,2.1)$ & $7.33(1 \mathrm{H}, \mathrm{dd}, J=8.8,2.0)$ & $7.32(1 \mathrm{H}, \mathrm{dd}, J=8.3,2.0)$ & $7.30(1 \mathrm{H}, \mathrm{dd}, J=8.3,2.3)$ \\
\hline \multicolumn{5}{|l|}{ Sugar moiety } \\
\hline $1^{\prime \prime}$ & $5.23(1 \mathrm{H}, \mathrm{d}, J=1.5)$ & $5.22(1 \mathrm{H}, \mathrm{d}, J=1.5)$ & $5.24(1 \mathrm{H}, \mathrm{d}, J=1.5)$ & $5.51(1 \mathrm{H}, \mathrm{d}, J=1.5)$ \\
\hline $2^{\prime \prime}$ & $4.28(1 \mathrm{H}, \mathrm{dd}, J=3.4,2.1)$ & $4.27(1 \mathrm{H}, \mathrm{dd}, J=3.4,1.5)$ & $4.29(1 \mathrm{H}, \mathrm{dd}, J=3.4,1.5)$ & $5.46(1 \mathrm{H}, \mathrm{dd}, J=3.4,1.5)$ \\
\hline $3^{\prime \prime}$ & $4.95(1 \mathrm{H}, \mathrm{dd}, J=9.4,3.4)$ & $4.95(1 \mathrm{H}, \mathrm{dd}, J=9.4,3.4)$ & $4.96(1 \mathrm{H}, \mathrm{dd}, J=9.4,3.4)$ & $3.76(1 \mathrm{H}, \mathrm{dd}, J=9.4,3.4)$ \\
\hline $4^{\prime \prime}$ & $3.47(1 \mathrm{H}, \mathrm{m})$ & $3.48(1 \mathrm{H}, \mathrm{m})$ & $3.44(1 \mathrm{H}, \mathrm{m})$ & $3.25(1 \mathrm{H}, \mathrm{m})$ \\
\hline $5^{\prime \prime}$ & $3.47(1 \mathrm{H}, \mathrm{m})$ & $3.48(1 \mathrm{H}, \mathrm{m})$ & $3.44(1 \mathrm{H}, \mathrm{m})$ & $3.25(1 \mathrm{H}, \mathrm{m})$ \\
\hline $6^{\prime \prime}$ & $0.89(3 \mathrm{H}, \mathrm{d}, J=5.7)$ & $0.89(3 \mathrm{H}, \mathrm{d}, J=5.5)$ & $0.89(3 \mathrm{H}, \mathrm{d}, J=5.5)$ & $0.91(3 \mathrm{H}, \mathrm{d}, J=5.5)$ \\
\hline \multicolumn{5}{|l|}{ Acyl moiety } \\
\hline $2^{\prime \prime \prime}$ & $7.50(1 \mathrm{H}, \mathrm{d}, J=8.6)$ & $7.32(1 \mathrm{H}, \mathrm{d}, J=2.0)$ & $7.74(1 \mathrm{H}, \mathrm{dd}, J=6.7,2.3)$ & $7.74(1 \mathrm{H}, \mathrm{dd}, J=6.7,2.3)$ \\
\hline $3^{\prime \prime \prime}$ & $6.82(1 \mathrm{H}, \mathrm{d}, J=8.6)$ & & $7.44(1 \mathrm{H}, \mathrm{m})$ & $7.43(1 \mathrm{H}, \mathrm{m})$ \\
\hline $4^{\prime \prime \prime}$ & & & $7.44(1 \mathrm{H}, \mathrm{m})$ & $7.43(1 \mathrm{H}, \mathrm{m})$ \\
\hline $5^{\prime \prime \prime}$ & $6.82(1 \mathrm{H}, \mathrm{d}, J=8.6)$ & $6.83(1 \mathrm{H}, \mathrm{d}, J=8.0)$ & $7.44(1 \mathrm{H}, \mathrm{m})$ & $7.43(1 \mathrm{H}, \mathrm{m})$ \\
\hline $6^{\prime \prime \prime}$ & $7.50(1 \mathrm{H}, \mathrm{d}, J=8.6)$ & $7.13(1 \mathrm{H}, \mathrm{dd}, J=8.0,2.0)$ & $7.74(1 \mathrm{H}, \mathrm{dd}, J=6.7,2.3)$ & $7.74(1 \mathrm{H}, \mathrm{dd}, J=6.7,2.3)$ \\
\hline $7^{\prime \prime \prime}$ & $7.62(1 \mathrm{H}, \mathrm{d}, J=16.0)$ & $7.61(1 \mathrm{H}, \mathrm{d}, J=16.0)$ & $7.72(1 \mathrm{H}, \mathrm{d}, J=16.0)$ & $7.67(1 \mathrm{H}, \mathrm{d}, J=16.0)$ \\
\hline $8^{\prime \prime \prime}$ & $6.42(1 \mathrm{H}, \mathrm{d}, J=16.0)$ & $6.50(1 \mathrm{H}, \mathrm{d}, J=16.0)$ & $6.67(1 \mathrm{H}, \mathrm{d}, J=16.0)$ & $6.64(1 \mathrm{H}, \mathrm{d}, J=16.0)$ \\
\hline $\mathrm{OCH}_{3}-3^{\prime \prime \prime}$ & & $3.83(3 \mathrm{H}, \mathrm{s})$ & & \\
\hline
\end{tabular}

Chemical shifts are given in ppm; coupling constants $J$ (in parentheses) are given in Hz.

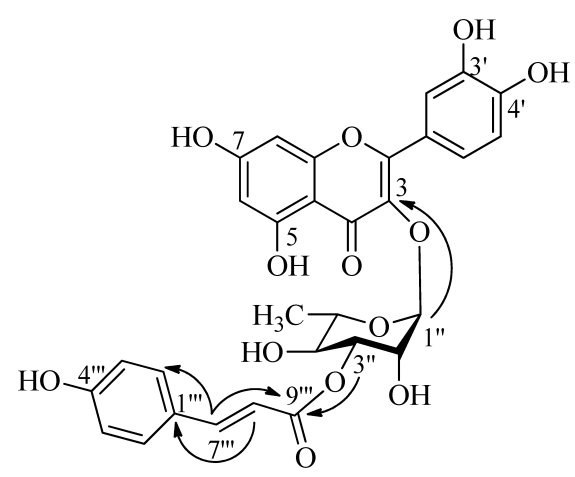

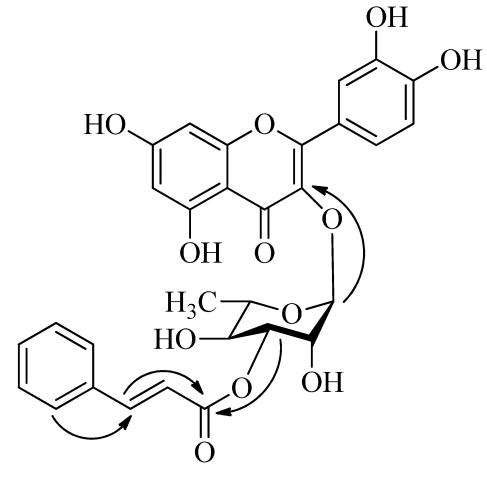

3

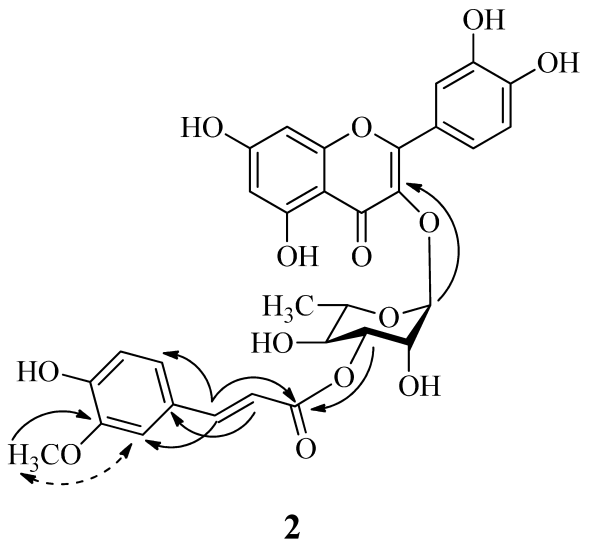

2

Fig. 1. Key HMBC and NOE Correlations for Compounds $\mathbf{1}-\mathbf{4}$

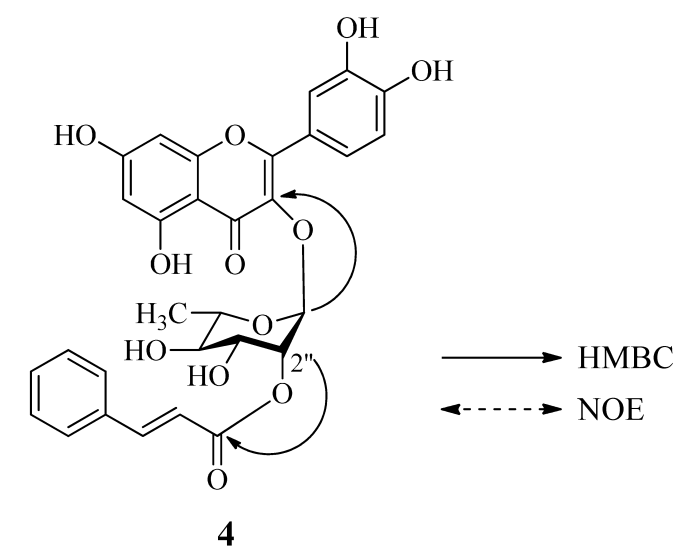

conjugated double bond $\left(1603 \mathrm{~cm}^{-1}\right)$. This evidence led to the conclusion that $\mathbf{1}$ is a flavonoid glycoside. In the ${ }^{1} \mathrm{H}-\mathrm{NMR}$ spectrum of 1 (Table 1), a 1,2,3,5-tetrasubstituted aromatic ring at $\delta_{\mathrm{H}} 6.42(1 \mathrm{H}, \mathrm{d}, J=2.0 \mathrm{~Hz}, \mathrm{H}-8)$ and $\delta_{\mathrm{H}} 6.23(1 \mathrm{H}, \mathrm{d}$, $J=2.0 \mathrm{~Hz}, \mathrm{H}-6)$ and a highly-deshielded signal at $\delta_{\mathrm{H}} 12.61$, which was assignable to a chelated $\mathrm{OH}$ group, indicated the 
Table 2. ${ }^{13} \mathrm{C}-\mathrm{NMR}(125 \mathrm{MHz})$ Data for Compounds $\mathbf{1}-\mathbf{4}$ (DMSO- $d_{6}$ with TMS as the Internal Standard)

\begin{tabular}{|c|c|c|c|c|}
\hline Position & 1 & 2 & 3 & 4 \\
\hline \multicolumn{5}{|c|}{ Aglycone moiety } \\
\hline 2 & 157.8 & 157.8 & 157.5 & 157.5 \\
\hline 3 & 134.9 & 135.0 & 134.6 & 133.5 \\
\hline 4 & 178.2 & 178.2 & 177.8 & 177.7 \\
\hline 5 & 161.7 & 161.7 & 161.5 & 161.4 \\
\hline 6 & 99.2 & 99.3 & 98.9 & 98.9 \\
\hline 7 & 164.7 & 164.8 & 164.4 & 164.5 \\
\hline 8 & 94.2 & 94.2 & 93.8 & 93.9 \\
\hline 9 & 156.9 & 156.9 & 156.7 & 156.6 \\
\hline 10 & 104.6 & 104.5 & 104.3 & 104.2 \\
\hline $1^{\prime}$ & 121.2 & 121.2 & 120.8 & 120.7 \\
\hline $2^{\prime}$ & 115.6 & 116.1 & 115.6 & 115.8 \\
\hline $3^{\prime}$ & 145.8 & 145.8 & 145.5 & 145.5 \\
\hline $4^{\prime}$ & 149.0 & 149.1 & 148.7 & 148.8 \\
\hline $5^{\prime}$ & 116.3 & 116.0 & 115.6 & 115.7 \\
\hline $6^{\prime}$ & 121.8 & 121.8 & 121.5 & 121.3 \\
\hline \multicolumn{5}{|c|}{ Sugar moiety } \\
\hline $1^{\prime \prime}$ & 102.5 & 102.6 & 102.1 & 98.5 \\
\hline $2^{\prime \prime}$ & 68.2 & 68.2 & 67.8 & 70.9 \\
\hline $3^{\prime \prime}$ & 74.2 & 74.2 & 74.2 & 72.0 \\
\hline $4^{\prime \prime}$ & 68.7 & 68.8 & 68.4 & 68.7 \\
\hline $5^{\prime \prime}$ & 71.3 & 71.3 & 70.9 & 71.6 \\
\hline $6^{\prime \prime}$ & 17.6 & 17.9 & 17.6 & 17.6 \\
\hline \multicolumn{5}{|c|}{ Acyl moiety } \\
\hline $1^{\prime \prime \prime}$ & 125.7 & 126.2 & 134.3 & 134.1 \\
\hline $2^{\prime \prime \prime}$ & 130.7 & 111.5 & 128.5 & 128.6 \\
\hline $3^{\prime \prime \prime}$ & 116.3 & 148.5 & 129.2 & 129.1 \\
\hline $4^{\prime \prime \prime}$ & 160.2 & 149.8 & 130.6 & 130.7 \\
\hline $5^{\prime \prime \prime}$ & 116.3 & 116.0 & 129.2 & 129.1 \\
\hline $6^{\prime \prime \prime}$ & 130.7 & 123.6 & 128.5 & 128.6 \\
\hline $7^{\prime \prime \prime}$ & 145.0 & 145.4 & 144.5 & 145.3 \\
\hline $8^{\prime \prime \prime}$ & 115.2 & 115.6 & 118.8 & 118.1 \\
\hline $9^{\prime \prime \prime}$ & 166.9 & 166.9 & 166.2 & 165.6 \\
\hline $\mathrm{OCH}_{3}-3^{\prime \prime \prime}$ & & 56.2 & & \\
\hline
\end{tabular}

Chemical shifts are given in ppm.

presence of 5,7-dihydroxy A ring structure in flavonol. A 1,2,4-trisubstituted aromatic ring at $\delta_{\mathrm{H}} 7.33(1 \mathrm{H}, \mathrm{dd}, J=8.3$, $\left.2.1 \mathrm{~Hz}, \mathrm{H}-6^{\prime}\right), \delta_{\mathrm{H}} 7.31\left(1 \mathrm{H}, \mathrm{d}, J=2.1 \mathrm{~Hz}, \mathrm{H}-2^{\prime}\right)$ and $\delta_{\mathrm{H}} 6.89(1 \mathrm{H}$, $\left.\mathrm{d}, J=8.3 \mathrm{~Hz}, \mathrm{H}-5^{\prime}\right)$ indicated the presence of a $3^{\prime}, 4^{\prime}$-dihydroxy $\mathrm{B}$ ring system in flavonol. Analysis of the ${ }^{13} \mathrm{C}-\mathrm{NMR}$ (Table 2) and distorsionless enhancement by polarization transfer (DEPT) spectra of $\mathbf{1}$ revealed the presence of two carbonyl groups, one methyl, sixteen methines, and eleven quaternary carbons. All protonated carbons of $\mathbf{1}$ were assigned by analysis of heteronuclear multiple quantum correlation (HMQC). In the ${ }^{13} \mathrm{C}-\mathrm{NMR}$ spectrum of $\mathbf{1}$, significant flavonol signals at $\delta_{\mathrm{C}}$ 157.8 (C-2), 134.9 (C-3), and 178.2 (C-4) were observed. From the heteronuclear multiple bond correlation (HMBC) experiment (Fig. 1.), the correlation between $\mathrm{H}-2^{\prime}$ and $\mathrm{C}-2, \mathrm{H}-6^{\prime}$ and $\mathrm{C}-2$, assumed that the aglycone of $\mathbf{1}$ was quercetin. A rhamnose was indicated by cross-peaks of the anomeric proton to $\delta_{\mathrm{H}} 5.23\left(1 \mathrm{H}, \mathrm{d}, J=1.5 \mathrm{~Hz}, \mathrm{H}-1^{\prime \prime}\right), \delta_{\mathrm{H}} 4.28(1 \mathrm{H}, \mathrm{dd}, J=3.4,1.5 \mathrm{~Hz}$, $\left.\mathrm{H}-2^{\prime \prime}\right), \delta_{\mathrm{H}} 4.95\left(1 \mathrm{H}, \mathrm{dd}, J=9.4,3.4 \mathrm{~Hz}, \mathrm{H}-3^{\prime \prime}\right), \delta_{\mathrm{H}} 3.47(2 \mathrm{H}, \mathrm{m}$, $\left.\mathrm{H}-4^{\prime \prime}, \mathrm{H}-5^{\prime \prime}\right)$, and $\delta_{\mathrm{H}} 0.89\left(3 \mathrm{H}, \mathrm{d}, J=5.7 \mathrm{~Hz}, \mathrm{H}-6^{\prime \prime}\right)$ in the ${ }^{1} \mathrm{H}-{ }^{1} \mathrm{H}-$ correlation spectroscopy (COSY) spectrum. Acid hydrolysis of 1 yielded quercetin and L-rhamnose, as determined by comparing retention time and polarity by HPLC analysis. The
HMBC analysis of $\mathbf{1}$ showed long-range correlations between anomeric proton at $\mathrm{H}-1$ " and $\mathrm{C}-3$ indicated that the L-rhamnose was located at C-3 in the molecule of $\mathbf{1}$. Moreover, the $J_{\mathrm{CH}}$ anomeric carbon proton cross-peak coupling constant at $\mathrm{C}^{\prime \prime}-1$ $\left(J_{\mathrm{CH}}=176.2 \mathrm{~Hz}\right)$ indicated that $\mathrm{C}-1$ of the L-rhamnose possessed the $\alpha$-configuration. ${ }^{24)}$ Current analysis and comparison with literature data indicated that $\mathbf{1}$ was a quercitrin derivative. $\left.{ }^{25}\right)$ In addition, a 1,4-disubstituted aromatic ring at $\delta_{\mathrm{H}} 7.50(2 \mathrm{H}, \mathrm{d}$, $\left.J=8.6 \mathrm{~Hz}, \mathrm{H}-2^{\prime \prime \prime}, 6^{\prime \prime \prime}\right)$ and $\delta_{\mathrm{H}} 6.82\left(2 \mathrm{H}, \mathrm{d}, J=8.6 \mathrm{~Hz}, \mathrm{H}-3^{\prime \prime \prime}, 5^{\prime \prime \prime}\right)$, a trans-olefin at $\delta_{\mathrm{H}} 7.62\left(1 \mathrm{H}, \mathrm{d}, J=16.0 \mathrm{~Hz}, \mathrm{H}-7^{\prime \prime \prime}\right)$ and $\delta_{\mathrm{H}} 6.42$ $\left(1 \mathrm{H}, \mathrm{d}, J=16.0 \mathrm{~Hz}, \mathrm{H}-8^{\prime \prime \prime}\right)$ were observed. HMBC correlations between H-7"' and $\delta_{\mathrm{C}} 166.9\left(\mathrm{C}-9^{\prime \prime \prime}\right), \mathrm{H}-7^{\prime \prime \prime}$ and $\delta_{\mathrm{C}} 130.7$ (C-2"', $\left.6^{\prime \prime \prime}\right), \mathrm{H}-8^{\prime \prime \prime}$ and $\delta_{\mathrm{C}} 125.7\left(\mathrm{C}-1^{\prime \prime \prime}\right)$ indicated the presence of an $(E)$ - $p$-coumaroyl moiety in the structure 1. Furthermore, the HMBC correlation between the H-3" and $\delta_{\mathrm{C}}$ C- 9 "' indicated that an $(E)$-p-coumaroyl moiety was located at the C-3" position $\left(\delta_{\mathrm{C}} 74.2\right)$ in the structure $\mathbf{1}$. Thus, the structure of $\mathbf{1}$ was determined to be $3^{2}$-(E)-p-coumaroylquercitrin.

$3^{\prime \prime}-(E)$-Feruloylquercitrin (2) was isolated as a yellow powder having a negative optical rotation $\left([\alpha]_{\mathrm{D}}^{25}-158^{\circ}\right)$, and its molecular formula was determined to be $\mathrm{C}_{31} \mathrm{H}_{28} \mathrm{O}_{14}$ by negative HR-FAB-MS. The ${ }^{1} \mathrm{H}$ - and ${ }^{13} \mathrm{C}-\mathrm{NMR}$ spectral data of 2 closely resembled those of $\mathbf{1}$, except for the presence of methoxy group at $\delta_{\mathrm{H}} 3.83(3 \mathrm{H}, \mathrm{s})$ and a 1,2,4-trisubstituted aromatic ring at $\delta_{\mathrm{H}} 7.32\left(1 \mathrm{H}, \mathrm{d}, J=2.0 \mathrm{~Hz}, \mathrm{H}-2^{\prime \prime \prime}\right), \delta_{\mathrm{H}} 7.13(1 \mathrm{H}$, $\left.\mathrm{dd}, J=8.0,2.0 \mathrm{~Hz}, \mathrm{H}-6^{\prime \prime \prime}\right)$, and $\delta_{\mathrm{H}} 6.83\left(1 \mathrm{H}, \mathrm{d}, J=8.0 \mathrm{~Hz}, \mathrm{H}-5^{\prime \prime \prime}\right)$. A rhamnose was indicated by cross-peaks of the anomeric proton to $\delta_{\mathrm{H}} 5.22\left(1 \mathrm{H}, \mathrm{d}, J=1.5 \mathrm{~Hz}, \mathrm{H}-1^{\prime \prime}\right), \delta_{\mathrm{H}} 4.27(1 \mathrm{H}, \mathrm{dd}$, $\left.J=3.4,1.5 \mathrm{~Hz}, \mathrm{H}-2^{\prime \prime}\right), \delta_{\mathrm{H}} 4.95\left(1 \mathrm{H}, \mathrm{dd}, J=9.4,3.4 \mathrm{~Hz}, \mathrm{H}-3^{\prime \prime}\right), \delta_{\mathrm{H}}$ $3.48\left(2 \mathrm{H}, \mathrm{m}, \mathrm{H}-4^{\prime \prime}, 5^{\prime \prime}\right)$, and $\delta_{\mathrm{H}} 0.89\left(3 \mathrm{H}, \mathrm{d}, J=5.5 \mathrm{~Hz}, \mathrm{H}-6^{\prime \prime}\right)$ in the ${ }^{1} \mathrm{H}-{ }^{1} \mathrm{H}-\mathrm{COSY}$ spectrum. Acid hydrolysis of $\mathbf{2}$ yielded quercetin and L-rhamnose. HMBC correlations between the methoxy protons and $\delta_{\mathrm{C}} 148.5\left(\mathrm{C}-3^{\prime \prime \prime}\right), \delta \mathrm{H} 7.61(1 \mathrm{H}, \mathrm{d}, J=16.0 \mathrm{~Hz}$, $\left.\mathrm{H}-7^{\prime \prime \prime}\right)$ and $\delta_{\mathrm{C}} 166.9$ (C-9'"'), H-7'" and $\delta_{\mathrm{C}} 111.5$ (C-2'"'), H-7"' and $\delta_{\mathrm{C}} 123.6\left(\mathrm{C}-6^{\prime \prime \prime}\right), \delta_{\mathrm{H}} 6.50\left(1 \mathrm{H}, \mathrm{d}, J=16.0 \mathrm{~Hz}, \mathrm{H}-8^{\prime \prime \prime}\right)$ and $\delta_{\mathrm{C}}$ $126.2\left(\mathrm{C}-1^{\prime \prime \prime}\right)$, indicated the presence of an $(E)$-feruloyl moiety in the structure of 2 . Nuclear Overhauser effect spectroscopy (NOESY) analysis (Fig. 1) of 2 further confirmed that the location of the methoxyl was at C- $3^{\prime \prime \prime}$ based on the correlation between the methoxy protons and $\mathrm{H}-2^{\prime \prime \prime}$. Moreover, the HMBC correlations between the H-3" and C-9"', H-1" and $\delta_{\mathrm{C}} 135.0$ $(\mathrm{C}-3)$ indicated that the $(E)$-feruloyl moiety was located at the C-3" position $\left(\delta_{\mathrm{C}}\right.$ 74.2) and L-rhamnose was located at the C-3 position $\left(\delta_{\mathrm{C}} 135.0\right)$. Thus, the structure of 2 was determined to be $3^{\prime \prime}-(E)$-feruloylquercitrin.

3"-(E)-Cinnamoylquercitrin (3) was isolated as a yellow powder having a negative optical rotation $\left([\alpha]_{\mathrm{D}}^{25}-125^{\circ}\right)$, and its molecular formula was determined to be $\mathrm{C}_{30} \mathrm{H}_{26} \mathrm{O}_{12}$ by positive HR-FAB-MS. The ${ }^{1} \mathrm{H}$ - and ${ }^{13} \mathrm{C}-\mathrm{NMR}$ spectral data of $\mathbf{3}$ were similar to those of $\mathbf{1}$ and $\mathbf{2}$, except for the presence of a monosubstituted aromatic ring at $\delta_{\mathrm{H}} 7.74(2 \mathrm{H}, \mathrm{dd}, J=6.7$, $\left.2.3 \mathrm{~Hz}, \mathrm{H}-2^{\prime \prime \prime}, 6^{\prime \prime \prime}\right)$, and $\delta_{\mathrm{H}} 7.44\left(3 \mathrm{H}, \mathrm{m}, \mathrm{H}-3^{\prime \prime \prime}, 4^{\prime \prime \prime}, 5^{\prime \prime \prime}\right)$. A rhamnose was indicated by cross-peaks of the anomeric proton to $\delta_{\mathrm{H}} 5.24\left(1 \mathrm{H}, \mathrm{d}, J=1.5 \mathrm{~Hz}, \mathrm{H}-1^{\prime \prime}\right), \delta_{\mathrm{H}} 4.29(1 \mathrm{H}, \mathrm{dd}, J=3.4$, $\left.1.5 \mathrm{~Hz}, \mathrm{H}-2^{\prime \prime}\right), \delta_{\mathrm{H}} 4.96\left(1 \mathrm{H}, \mathrm{dd}, J=9.4,3.4 \mathrm{~Hz}, \mathrm{H}-3^{\prime \prime}\right), \delta_{\mathrm{H}} 3.44$ $\left(2 \mathrm{H}, \mathrm{m}, \mathrm{H}-4^{\prime \prime}, 5^{\prime \prime}\right)$, and $\delta_{\mathrm{H}} 0.89\left(3 \mathrm{H}, \mathrm{d}, J=5.5 \mathrm{~Hz}, \mathrm{H}-6^{\prime \prime}\right)$ in the ${ }^{1} \mathrm{H}-{ }^{1} \mathrm{H}-\mathrm{COSY}$ spectrum. Acid hydrolysis of $\mathbf{3}$ yielded quercetin and L-rhamnose. The HMBC correlations between $\mathrm{H}-2^{\prime \prime \prime}$, $6^{\prime \prime \prime}$ and $\delta_{\mathrm{C}} 144.5\left(\mathrm{C}-7^{\prime \prime \prime}\right), \delta_{\mathrm{H}} 7.72\left(1 \mathrm{H}, \mathrm{d}, J=16.0 \mathrm{~Hz}, \mathrm{H}-7^{\prime \prime \prime}\right)$ and $\delta_{\mathrm{C}} 166.2\left(\mathrm{C}-9^{\prime \prime \prime}\right)$, indicated the presence of an $(E)$-cinnamoyl moiety in structure 3. Moreover, the HMBC correlations be- 


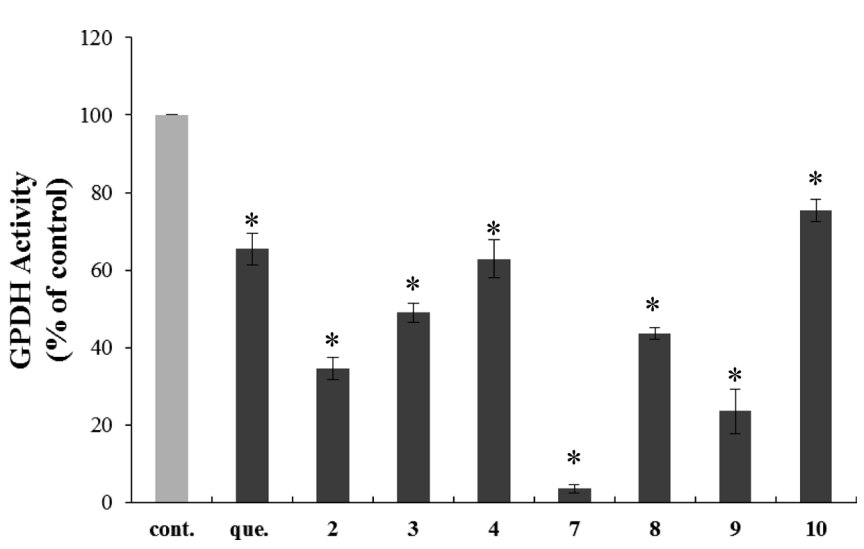

Fig. 2. Effect of $\mathbf{2 - 4}, \mathbf{7 - 1 0}$ on GPDH Activity in Cultured 3T3-L1 Adipocytes

Cells were treated with the compounds $(30 \mu \mathrm{m})$ on days 0 and 3 after the initiation of differentiation. On day 8 , the intracellular GPDH activity of the cells was measured. Non-treated control is at $100 \%$. Results are expressed as mean \pm S.E. of three individual experiments. ${ }^{*} p<0.05 v s$. control.

tween the H-3" and $\delta_{\mathrm{C}} 166.2\left(\mathrm{C}-9^{\prime \prime \prime}\right), \mathrm{H}-1^{\prime \prime}$ and $\delta_{\mathrm{C}} 134.6(\mathrm{C}-3)$ indicated that the $(E)$-cinnamoyl moiety was located at the C-3" position $\left(\delta_{\mathrm{C}} 74.2\right)$ and L-rhamnose was located at the C-3 position $\left(\delta_{\mathrm{C}}\right.$ 134.6). Thus, the structure of $\mathbf{3}$ was determined to be $3^{\prime \prime}-(E)$-cinnamoylquercitrin.

$2^{\prime \prime}$-(E)-Cinnamoylquercitrin (4) was isolated as a yellow powder having a negative optical rotation $\left([\alpha]_{\mathrm{D}}^{25}-143^{\circ}\right)$, and its molecular formula was determined to be $\mathrm{C}_{30} \mathrm{H}_{26} \mathrm{O}_{12}$ by negative HR-FAB-MS. The ${ }^{1} \mathrm{H}$ - and ${ }^{13} \mathrm{C}-\mathrm{NMR}$ spectral data of 4 was closely resembled those of $\mathbf{3}$, except for a sugar moiety. A rhamnose was indicated by cross-peaks of the anomeric proton to $\delta_{\mathrm{H}} 5.51\left(1 \mathrm{H}, \mathrm{d}, J=1.5 \mathrm{~Hz}, \mathrm{H}-1^{\prime \prime}\right), \delta_{\mathrm{H}} 5.46(1 \mathrm{H}, \mathrm{dd}$, $\left.J=3.4,1.5 \mathrm{~Hz}, \mathrm{H}-2^{\prime \prime}\right), \delta_{\mathrm{H}} 3.76\left(1 \mathrm{H}, \mathrm{dd}, J=9.4,3.4 \mathrm{~Hz}, \mathrm{H}-3^{\prime \prime}\right), \delta_{\mathrm{H}}$ $3.25\left(2 \mathrm{H}, \mathrm{m}, \mathrm{H}-4^{\prime \prime}, 5^{\prime \prime}\right)$, and $\delta_{\mathrm{H}} 0.91\left(3 \mathrm{H}, \mathrm{d}, J=5.5 \mathrm{~Hz}, \mathrm{H}-6^{\prime \prime}\right)$ in the ${ }^{1} \mathrm{H}-{ }^{1} \mathrm{H}-\mathrm{COSY}$ spectrum. Acid hydrolysis of $\mathbf{4}$ yielded quercetin and L-rhamnose. The ${ }^{1} \mathrm{H}-\mathrm{NMR}$ signal of $\mathrm{H}-2$ " of $\mathbf{4}$ was shifted downfield compared with that of $\mathbf{3}(\Delta+1.17 \mathrm{ppm}$ value difference), and the HMBC correlation between $\mathrm{H}-2$ " and $\delta_{\mathrm{C}}$ 165.6 (C-9"') of 4 indicated that an $(E)$-cinnamoyl moiety was located at $\mathrm{C}-2^{\prime \prime}$ position. Thus, the structure 4 was determined to be $2^{\prime \prime}-(E)$-cinnamoylquercitrin.

The known isolated compounds were readily identified by comparison of physical and spectral data with corresponding literature values. These compounds included the six flavonols, quercetin (5), ${ }^{25)}$ isorhamnetin (6), ${ }^{26)}$ rhamnetin (7), ${ }^{27)}$ quercitrin $(\mathbf{8}),{ }^{25)}$ kaempferol (9), ${ }^{25)}$ and afzelein $(\mathbf{1 0}),{ }^{28)}$ the five flavons, chrysoeriol (11) ${ }^{29)}$ apigenin (12), ${ }^{30)} \operatorname{tricin}(\mathbf{1 3}),{ }^{31)}$ luteolin (14), ${ }^{32)}$ and amentoflavone (15), ${ }^{33)}$ the flavanonol, taxifolin (16), ${ }^{34)}$ the chalcone, isoliquiritigenin $(\mathbf{1 7}),{ }^{35)}$ the dithiodicarboxylic acid, 3,3'-dithiodipropanoic acid $(\mathbf{1 8}),{ }^{36)}$ the indole derivative, indole-3-carboxylic acid (19), ${ }^{37)}$ the alloxazine derivative, 7,8-dimethylalloxazine (20), ${ }^{38)}$ the phenylpropanoid, (E)-p-coumaric acid (21), ${ }^{39)}$ and the mono-terpenoid, (6S)-menthiafolic acid (22). ${ }^{40)}$ Compounds 6, 7, 11-22 were isolated for the first time from the flower of A. julibrissin.

To determine non-toxic concentrations, 3T3-L1 cells were treated with various concentrations $(10,30,100 \mu \mathrm{M})$ of $\mathbf{1}-\mathbf{2 2}$, and the cell viability was measured by MTT assay. None of the compounds were cytotoxic at concentrations up to $30 \mu \mathrm{m}$. Thus, we treated with this concentration. Compounds $\mathbf{1 - 2 2}$ were tested to verify their effect on TG accumulation (Table 3). Quercetin (que.), which has been reported to have inhibitory effects on triglyceride accumulation, was used as a positive control. Our results indicated that $\mathbf{1} \mathbf{- 2 2}$ inhibited intracellular TG accumulation in 3T3-L1 adipocytes in the range of $9.2-92.5 \%$ at $30 \mu \mathrm{M}$. Compounds $\mathbf{3}, \mathbf{4}, \mathbf{8}-\mathbf{1 0}$ exhibited similar extent TG inhibitory activity to the positive control. Among the 22 compounds being tested, compound $\mathbf{2}$ exhibited the highest inhibitory activity against intracellular TG accumulation (92.5\%), whereas compound $\mathbf{8}$ possessing the basic structure of $\mathbf{2}$, exhibited TG inhibitory activity equal to that of the positive control. These data indicate that the presence of an $(E)$-feruloyl moiety in the molecule is possibly important for potent inhibitory activity. In addition, 7 exhibited potent inhibitory activity against intracellular TG accumulation (76.5\%) compared to that of the positive control. These results indicate that the presence of a methoxy group at C-7 position could be important. Measurements of the GPDH activity treated with $\mathbf{2}-\mathbf{4}, \mathbf{7}-\mathbf{1 0}$ were shown in Fig. 2. The cytosolic enzyme GPDH appears to have an important role in the conversion of glycerol into triglyceride, which is the hallmark of 3T3-L1 preadipocyte differentiation. The GPDH activity in the cells treated these compounds was lower than in the untreated group. In particular, 7 potently inhibited GPDH activity. The mechanism of adipogenesis inhibition of the AJ ext. and 1-22 may be related to peroxisome proliferator-activated receptor- $\gamma$ and CCAAT/enhancer-binding protein $\alpha$, which is

Table 3. Effect of Compounds $\mathbf{1}-\mathbf{2 2}$ on TG Accumulation in Cultured 3T3-L1 Adipocytes

\begin{tabular}{|c|c|c|c|}
\hline Compounds & Inhibition (\%) & Compounds & Inhibition (\%) \\
\hline 1 & $38.4 \pm 1.4$ & 13 & $22.4 \pm 6.7$ \\
\hline 2 & $92.5 \pm 0.7 *$ & 14 & $9.2 \pm 5.0$ \\
\hline 3 & $49.4 \pm 2.6^{*}$ & 15 & $24.7 \pm 0.9$ \\
\hline 4 & $53.9 \pm 1.7 *$ & 16 & $25.3 \pm 3.4$ \\
\hline 6 & $35.3 \pm 0.9$ & 17 & $12.5 \pm 9.3$ \\
\hline 7 & $76.5 \pm 4.3^{*}$ & 18 & $28.0 \pm 2.8$ \\
\hline 8 & $50.9 \pm 4.3^{*}$ & 19 & $25.2 \pm 10.5$ \\
\hline 9 & $53.0 \pm 2.9^{*}$ & 20 & $19.8 \pm 1.8$ \\
\hline 10 & $49.9 \pm 1.8^{*}$ & 21 & $11.9 \pm 6.2$ \\
\hline 11 & $27.9 \pm 6.5$ & 22 & $30.7 \pm 4.6$ \\
\hline 12 & $25.9 \pm 1.4$ & que. (5) & $38.5 \pm 3.4$ \\
\hline
\end{tabular}

Cells were treated with compounds $\mathbf{1}-\mathbf{2 2}(30 \mu \mathrm{M})$ on days 0 and 3 . On day 8 the intracellular TG content of the cells was measured. Results are expressed as mean \pm S.E. of three individual experiments. ${ }^{*} p<0.05 v s$. control (Student's $t$-test.) 
Table 4. Effect of Compounds $\mathbf{1}-\mathbf{2 2}$ on Glucose Uptake in 3T3-L1 Cells

\begin{tabular}{|c|c|c|c|}
\hline Compounds & Inhibition (\%) & Compounds & Inhibition (\%) \\
\hline 1 & $61.6 \pm 1.1^{*}$ & 13 & $29.5 \pm 3.3$ \\
\hline 2 & $69.9 \pm 2.0 *$ & 14 & $49.9 \pm 1.2 *$ \\
\hline 3 & $55.2 \pm 1.0 *$ & 15 & $71.7 \pm 1.1^{*}$ \\
\hline 4 & $37.3 \pm 1.7 *$ & 16 & $-20.9 \pm 2.5$ \\
\hline 6 & $62.4 \pm 2.1^{*}$ & 17 & $17.9 \pm 7.1$ \\
\hline 7 & $28.3 \pm 1.7$ & 18 & $-21.0 \pm 1.9$ \\
\hline 8 & $-6.7 \pm 4.1$ & 19 & $11.8 \pm 5.9$ \\
\hline 9 & $56.6 \pm 1.7^{*}$ & 20 & $5.5 \pm 4.5$ \\
\hline 10 & $1.8 \pm 2.8$ & 21 & $5.0 \pm 5.7$ \\
\hline 11 & $41.0 \pm 1.7^{*}$ & 22 & $-13.1 \pm 5.4$ \\
\hline 12 & $24.6 \pm 0.7$ & que. (5) & $20.3 \pm 1.7$ \\
\hline
\end{tabular}

After cell differentiation, the medium was replaced with serum-free DMEM for $2 \mathrm{~h}$, and then cells were washed and incubated in KRH buffer containing insulin $(200 \mathrm{~nm})$ for $10 \mathrm{~min}$. After exposed to insulin, they were treated with samples in KRH buffer for $15 \mathrm{~min}$. After incubation, $\left[1-{ }^{3} \mathrm{H}\right]-2-\mathrm{deoxy}-\mathrm{D}-\mathrm{glucose}(0.25 \mu \mathrm{Ci} / \mathrm{mL})$ was added, and incubation was continued for $10 \mathrm{~min}$. The cells were solubilized with $0.1 \%$ SDS. The incorporated radioactivity was measured by liquid scintillation counting. Results are expressed as mean \pm S.E. of three individual experiments. ${ }^{*} p<0.05 v s$. control (Student's $t$-test).

the primary adipogenic transcription factor involved in adipocyte differentiation. ${ }^{41,42)}$ Moreover, we examined the effect of $\mathbf{1} \mathbf{2 2}$ on the uptake of 2-deoxyglucose (Table 4). Compounds $1-4,6,9,11,14,15$ inhibited glucose uptake in 3T3-L1 adipocyte. Our results indicate that the AJ ext. and compounds 1-22 may prevent obesity, which is a serious health problem in industrialized countries, via inhibiting preadipocyte differentiation and glucose uptake in mature adipocytes.

\section{Experimental}

General Experimental Procedure Optical rotation was measured in $\mathrm{MeOH}$ on a JASCO P-1020 polarimeter. The UV spectra were obtained in $\mathrm{MeOH}$ on a JASCO V-550 spectrophotometer, and the IR spectra were recorded on a JASCO IR A-2 spectrophotometer. The NMR spectra were recorded on a JEOL ECX-500 spectrometer $\left({ }^{1} \mathrm{H}-\mathrm{NMR}\right.$ : $500 \mathrm{MHz},{ }^{13} \mathrm{C}-\mathrm{NMR}$ : $125 \mathrm{MHz}$ ), with tetramethylsilane (TMS) as an internal standard. Mass spectrum data were obtained on a JEOL GCmate spectrometer. For column chromatography, silica gel $60 \mathrm{~N}$ (Kanto Chemical Corp., Tokyo, Japan), YMC GEL ODS-A (YMC Co., Ltd., Kyoto, Japan), and Sephadex LH-20 (GE Healthcare) were used. TLC were performed on TLC plates (thickness: $0.25 \mathrm{~mm}, \mathrm{~F} 254$, Merck), and compounds were visualized by spraying with $5 \%(\mathrm{v} / \mathrm{v}) \mathrm{H}_{2} \mathrm{SO}_{4}$ in EtOH and Vanillin reagent. HPLC was performed on a JASCO PU-1580 apparatus equipped with a JASCO UV-1575 detector and Shodex OR-2 optical rotation (OR) detector. Cosmosil $5 \mathrm{C}_{18}$-MS-II $(\Phi 10 \times 250 \mathrm{~mm}$ and $\Phi 4.6 \times 250 \mathrm{~mm}$, Nacalai tesque, Kyoto, Japan), Cosmosil Cholester $(\Phi 10 \times 250 \mathrm{~mm}$, Nacalai tesque), and Cosmosil $\pi$ nap $(\Phi 10 \times 250 \mathrm{~mm}$, Nacalai tesque) were used for preparative purpose. Cosmosil Sugar D $(\Phi 4.6 \times 250 \mathrm{~mm}$, Nacalai tesque) was used for confirm the presence of glycosyl moiety. The radioactivity was detected Tri-carb 2800TR scintillation counter (Perkin Elmer, Inc.).

Plant Material Dried flowers of A. juliburissin Durazz. were collected from Hubei, China, in June 2007. A voucher specimen has been deposited at the School of Pharmacy, Nihon University.

Extraction and Isolation The flowers of $A$. julibrissin $(15.0 \mathrm{~kg})$ were extracted three times with $90 \%$ aqueous EtOH. The solvent was evaporated under reduced pressure from the combined extract and ethanolic extract was yielded $(3.5 \mathrm{~kg})$. The extract was suspended in $\mathrm{H}_{2} \mathrm{O}$ and partitioned with $n$ - hexane $(4 \times 1: 1 \mathrm{v} / \mathrm{v}), \mathrm{CHCl}_{3}(4 \times 1: 1 \mathrm{v} / \mathrm{v})$, EtOAc $(4 \times 1: 1 \mathrm{v} / \mathrm{v})$, and $n-\mathrm{BuOH}(4 \times 1: 1 \mathrm{v} / \mathrm{v})$, successively. The amounts extracted were $114.9,102.3,165.5$, and $429.0 \mathrm{~g}$, respectively, and the residual aqueous extract yielded $2560 \mathrm{~g}$ of material. The EtOAc extract was subjected to silica gel column chromatography (C.C.), $\left[\mathrm{CHCl}_{3}-\mathrm{MeOH}(100: 0 \rightarrow 0: 100 \mathrm{v} / \mathrm{v})\right]$. The fractions ( $1 \mathrm{~L}$ each) were combined according to the results of TLC monitoring into 4 fractions, [Fr. E-1 (716 mg), E-2 $(9.37 \mathrm{~g})$, E-3 (22.7 g), E-4 (162 g)]. Fr. E-2 was subjected to silica gel C. C. $[n$-hexane-EtOAc $(100: 0 \rightarrow 0: 100 \mathrm{v} / \mathrm{v})]$ to yield Fr. E-21-E-2-10. Fr. E-2-2 (911.4 mg) was purified by HPLC with $0.1 \%$ TFA-MeOH $(57: 43 \mathrm{v} / \mathrm{v})$ to yield $18(230 \mathrm{mg})$ and 22 (342 mg). Fr. E-2-4 (4.21 g) was subjected to ODS C.C. $\left[\mathrm{H}_{2} \mathrm{O}-\right.$ $\mathrm{MeOH}(90: 10 \rightarrow 0: 100 \mathrm{v} / \mathrm{v})]$ to yield Fr. E-2-4-1-E-2-4-9. Fr. E-2-4-3 (477 mg) was purified by reversed-phase HPLC with $0.1 \%$ trifluoroacetic acid (TFA)-MeOH $(50: 50 \mathrm{v} / \mathrm{v})$ to yield 19 (4.4 mg) and 21 (1.8 mg). E-2-4-5 (79 mg) was purified by reversed-phase HPLC with $0.1 \%$ TFA-MeOH $(50: 50 \mathrm{v} / \mathrm{v})$ to yield $20(10.5 \mathrm{mg})$. Fr. E-2-4-8 $(270 \mathrm{mg})$ was then applied to a Sephadex LH-20 C.C. eluted with $\mathrm{H}_{2} \mathrm{O}-\mathrm{MeOH}(40: 60 \mathrm{v} / \mathrm{v})$ to yield Fr. E-2-4-8-1-E-2-4-8-6. Fr. E-2-4-8-3 (10 mg) was purified by reversed-phase HPLC with $0.1 \%$ TFA-MeOH (37: $63 \mathrm{v} / \mathrm{v})$ to yield $\mathbf{1 1}(2.6 \mathrm{mg}), \mathbf{1 2}(1.4 \mathrm{mg})$ and $\mathbf{1 3}(3.2 \mathrm{mg})$. Fr. E-2-4-8-4 (9.7 mg) was purified by HPLC with $0.1 \%$ TFA-MeOH $(33: 67 \mathrm{v} / \mathrm{v})$ to yield $14(2.1 \mathrm{mg})$ and $17(2.1 \mathrm{mg})$. Compound 9 (36 mg) was crystallized from Fr. E-2-4-8-6 using $\mathrm{MeOH}$. Fr. E-2-4-8-5 (12 mg) was purified by HPLC with $0.1 \%$ TFA-MeOH $(33: 67 \mathrm{v} / \mathrm{v})$ to yield $6(2.1 \mathrm{mg})$ and 7 $(2.1 \mathrm{mg})$. Fr. E-3 was subjected to silica gel C.C. [n-HexaneEtOAc $(100: 0 \rightarrow 0: 100 \mathrm{v} / \mathrm{v})]$ to yield Fr. E-3-1-E-3-5. Fr. E-3-2 $(259 \mathrm{mg})$ was purified by HPLC with $0.1 \%$ TFA-MeOH $(70: 30)$ to afford $5(64 \mathrm{mg})$ and $16(2.7 \mathrm{mg})$. Fr. E-3-3 (2.09 g) was subjected to ODS C.C. $\left[\mathrm{H}_{2} \mathrm{O}-\mathrm{MeOH}(90: 10 \rightarrow 0: 100 \mathrm{v} / \mathrm{v})\right]$ to yield Fr. E-3-3-1-E-3-3-8. Fr. E-3-3-4 (112 mg) was purified by HPLC with $0.1 \%$ TFA-MeOH $(50: 50 \mathrm{v} / \mathrm{v})$ to yield 1 (18.6 mg) and 2 (19.5 mg). Fr. E-3-3-5 (117 mg) was separated by HPLC with $0.1 \%$ TFA- $\mathrm{CH}_{3} \mathrm{CN}(60: 40 \mathrm{v} / \mathrm{v})$ to yield Fr. E3-3-5-1-E-3-3-5-5. Fr. E-3-3-5-4 (10.6 mg) was purified by HPLC with $0.1 \%$ TFA-MeOH $(32: 68 \mathrm{v} / \mathrm{v})$ to yield $15(3.3 \mathrm{mg})$. Fr. E-3-3-5-5 (10.6 mg) was purified by HPLC with $0.1 \%$ TFA-MeOH $(40: 60 \mathrm{v} / \mathrm{v})$ to yield $3(4.5 \mathrm{mg})$ and $4(3.3 \mathrm{mg})$. Fr. E-4 $(250 \mathrm{mg} / 162.9 \mathrm{~g})$ was purified by HPLC with $0.1 \%$ TFA$\mathrm{MeOH}(40: 60 \mathrm{v} / \mathrm{v})$ to yield $8(129 \mathrm{mg})$ and $10(6.6 \mathrm{mg})$. 


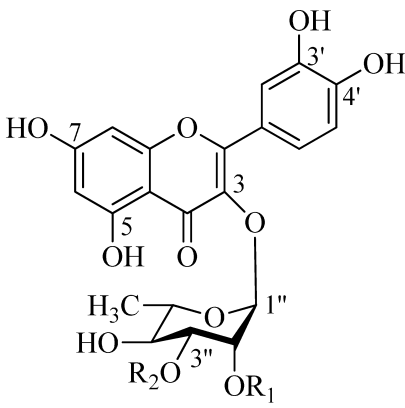

$1 \quad \mathrm{R}_{1}=\mathrm{H}, \mathrm{R}_{2}=(E)$ - $p$-coumaroyl

$2 \mathrm{R}_{1}=\mathrm{H}, \mathrm{R}_{2}=(E)$-feruloyl

$3 \mathrm{R}_{1}=\mathrm{H}, \mathrm{R}_{2}=(E)$-cinnamoyl

$4 \mathrm{R}_{1}=(E)$-cinnamoyl, $\mathrm{R}_{2}=\mathrm{H}$<smiles>[R]c1cc(O)c2c(=O)c([R])c(-c3cc([R3])c(O)c([Y6])c3)oc2c1</smiles>

$5 \mathrm{R}_{1}=\mathrm{OH}, \mathrm{R}_{2}=\mathrm{OH}, \mathrm{R}_{3}=\mathrm{OH}, \mathrm{R}_{4}=\mathrm{H}$

$6 \quad \mathrm{R}_{1}=\mathrm{OH}, \mathrm{R}_{2}=\mathrm{OH}, \mathrm{R}_{3}=\mathrm{OCH}_{3}, \mathrm{R}_{4}=\mathrm{H}$

$7 \quad \mathrm{R}_{1}=\mathrm{OH}, \mathrm{R}_{2}=\mathrm{OCH}_{3}, \mathrm{R}_{3}=\mathrm{OH}, \mathrm{R}_{4}=\mathrm{H}$

$8 \mathrm{R}_{1}=\mathrm{O}-\alpha-\mathrm{L}-\mathrm{Rha}, \mathrm{R}_{2}=\mathrm{OH}, \mathrm{R}_{3}=\mathrm{OH}, \mathrm{R}_{4}=\mathrm{H}$

$9 \mathrm{R}_{1}=\mathrm{OH}, \mathrm{R}_{2}=\mathrm{OH}, \mathrm{R}_{3}=\mathrm{H}, \mathrm{R}_{4}=\mathrm{H}$

$10 \mathrm{R}_{1}=\mathrm{O}-\alpha$-L-Rha, $\mathrm{R}_{2}=\mathrm{OH}, \mathrm{R}_{3}=\mathrm{H}, \mathrm{R}_{4}=\mathrm{H}$

$11 \mathrm{R}_{1}=\mathrm{H}, \mathrm{R}_{2}=\mathrm{OH}, \mathrm{R}_{3}=\mathrm{OCH}_{3}, \mathrm{R}_{4}=\mathrm{H}$

$12 \mathrm{R}_{1}=\mathrm{H}, \mathrm{R}_{2}=\mathrm{OH}, \mathrm{R}_{3}=\mathrm{H}, \mathrm{R}_{4}=\mathrm{H}$

$13 \mathrm{R}_{1}=\mathrm{H}, \mathrm{R}_{2}=\mathrm{OH}, \mathrm{R}_{3}=\mathrm{OCH}_{3}, \mathrm{R}_{4}=\mathrm{OCH}_{3}$

$14 \mathrm{R}_{1}=\mathrm{H}, \mathrm{R}_{2}=\mathrm{OH}, \mathrm{R}_{3}=\mathrm{OH}, \mathrm{R}_{4}=\mathrm{H}$<smiles>O=c1cc(-c2ccc(O)c(-c3c(O)cc(O)c4c(=O)cc(-c5ccc(O)cc5)oc34)c2)oc2cc(O)cc(O)c12</smiles>

15<smiles>O=C(O)CCSSCCC(=O)O</smiles>

18<smiles>O=C(O)/C=C/c1ccc(O)cc1</smiles>

21<smiles>O=C1c2c(O)cc(O)cc2O[C@H](c2ccc(O)c(O)c2)[C@@H]1O</smiles>

16<smiles>O=C(O)c1c[nH]c2ccccc12</smiles>

19<smiles>O=C(/C=C/c1ccc(O)cc1)c1ccc(O)cc1O</smiles>

17<smiles>Cc1cc2nc3[nH]c(=O)[nH]c(=O)c3nc2cc1C</smiles>

20<smiles>C=C[C@](C)(O)CC/C=C(\C)C(=O)O</smiles>

22

Chart 1. Structures of Compounds $\mathbf{1}-\mathbf{2 2}$

$3^{\prime \prime}-(E)$-p-Coumaroylquercitrin (1): Yellow powder. $[\alpha]_{\mathrm{D}}^{25}$ $-146^{\circ}(c=0.5, \mathrm{MeOH})$. UV $\lambda_{\max }(\mathrm{MeOH}) \mathrm{nm}(\log \varepsilon): 267$ (3.18), 315 (3.32). IR (KBr) $v_{\max } \mathrm{cm}^{-1}: 3378(\mathrm{OH}), 1654$ (conj. $\mathrm{C}=\mathrm{O}$ ), 1603 (conj. $\mathrm{C}=\mathrm{C}$ ). FAB-MS (negative mode) $\mathrm{m} / \mathrm{z}: 593$ $[\mathrm{M}-\mathrm{H}]^{-}$. HR-FAB-MS (negative mode) $\mathrm{m} / \mathrm{z}$ : 593.1301 (Calcd for $\left.\mathrm{C}_{30} \mathrm{H}_{25} \mathrm{O}_{13}, 593.1294\right)$. ${ }^{1} \mathrm{H}$ - and ${ }^{13} \mathrm{C}-\mathrm{NMR}$ spectral data of $\mathbf{1}$ are presented in Tables 1 and 2 .

$3^{\prime \prime}-(E)$-Feruloylquercitrin (2): Yellow powder. $[\alpha]_{D}^{25}-158^{\circ}$ $(c=0.5, \mathrm{MeOH})$. UV $\lambda_{\max }(\mathrm{MeOH}) \mathrm{nm}(\log \varepsilon): 267$ (2.91), 333 (2.99). IR (KBr) $v_{\max } \mathrm{cm}^{-1}: 3422(\mathrm{OH}), 1653$ (conj. $\left.\mathrm{C}=\mathrm{O}\right), 1603$ (conj. $\mathrm{C}=\mathrm{C}$ ). FAB-MS (negative mode) $\mathrm{m} / z$ : $623[\mathrm{M}-\mathrm{H}]^{-}$. HRFAB-MS (negative mode) $m / z$ : 623.1398 (Calcd for $\mathrm{C}_{31} \mathrm{H}_{27} \mathrm{O}_{14}$,
623.1399). ${ }^{1} \mathrm{H}$ - and ${ }^{13} \mathrm{C}-\mathrm{NMR}$ spectral data of $\mathbf{2}$ are presented in Tables 1 and 2.

$3^{\prime \prime}-(E)$-Cinnamoylquercitrin (3): Yellow powder. $[\alpha]_{D}^{25}$ $-125^{\circ}(c=0.25, \mathrm{MeOH})$. UV $\lambda_{\max }(\mathrm{MeOH}) \mathrm{nm}(\log \varepsilon): 270$ (3.29), 340 (2.85). IR (KBr) $v_{\max } \mathrm{cm}^{-1}: 3422(\mathrm{OH}), 1653$ (conj. $\mathrm{C}=\mathrm{O}$ ), 1607 (conj. $\mathrm{C}=\mathrm{C}$ ). FAB-MS (positive mode) $\mathrm{m} / \mathrm{z}: 579$ $[\mathrm{M}+\mathrm{H}]^{+}$. HR-FAB-MS (positive mode) $\mathrm{m} / \mathrm{z}: 579.1496$ (Calcd for $\left.\mathrm{C}_{30} \mathrm{H}_{27} \mathrm{O}_{12}, 579.1501\right) .{ }^{1} \mathrm{H}$ - and ${ }^{13} \mathrm{C}-\mathrm{NMR}$ spectral data of $\mathbf{3}$ are presented in Tables 1 and 2.

$2^{\prime \prime}-(E)$-Cinnamoylquercitrin (4): Yellow powder. $[\alpha]_{\mathrm{D}}^{25}-143^{\circ}$ $(c=0.5, \mathrm{MeOH})$. UV $\lambda_{\max }(\mathrm{MeOH}) \mathrm{nm}(\log \varepsilon): 267$ (3.07), 333 (2.54). IR (KBr) $v_{\max } \mathrm{cm}^{-1}: 3418$ (hydroxyl), 1652 (conj. 
$\mathrm{C}=\mathrm{O}$ ), 1606 (conj. $\mathrm{C}=\mathrm{C}$ ). FAB-MS (negative mode) $\mathrm{m} / \mathrm{z}: 577$ $[\mathrm{M}-\mathrm{H}]^{-}$. HR-FAB-MS (negative mode) $\mathrm{m} / \mathrm{z}$ : 577.1350 (Calcd for $\left.\mathrm{C}_{30} \mathrm{H}_{25} \mathrm{O}_{12}, 577.1345\right)$. UV $\lambda_{\max }(\mathrm{MeOH}) \mathrm{nm}(\log \varepsilon): 267$ (3.07), 333 (2.54). ${ }^{1} \mathrm{H}$ - and ${ }^{13} \mathrm{C}-\mathrm{NMR}$ spectral data of 4 are presented in Tables 1 and 2 .

Acid Hydrolysis of $\mathbf{1 - 4}$ A solution of $\mathbf{1}-\mathbf{4}(2 \mathrm{mg})$ in $10 \%$ TFA was heated at $100^{\circ} \mathrm{C}$ for $12 \mathrm{~h}$. After cooling, the reaction mixture was evaporated, and partitioned between EtOAc and $\mathrm{H}_{2} \mathrm{O}$. The EtOAc and $\mathrm{H}_{2} \mathrm{O}$ layers were concentrated under reduced pressure. The EtOAc layer was analyzed by HPLC under the following conditions: column, Cosmosil $5 \mathrm{C}_{18}$-MS-II $(\Phi 4.6 \times 250 \mathrm{~mm})$, solvent, $0.1 \%$ TFA-MeOH $(50: 50$ $\mathrm{v} / \mathrm{v})$, flow rate, $1.0 \mathrm{~mL} / \mathrm{min}$, detection, UV $(254 \mathrm{~nm})$. Quercetin was identified in the EtOAc layer by comparing the retention time of the hydrolysis product with that of an authentic sample: $t_{\mathrm{R}}(\min )$ 9.2. The $\mathrm{H}_{2} \mathrm{O}$ layer was also analyzed by HPLC under the following condition: column, Cosmosil Sugar D $(\Phi 4.6 \times 250 \mathrm{~mm})$, solvent, $\mathrm{H}_{2} \mathrm{O}-\mathrm{CH}_{3} \mathrm{CN}(20: 80 \mathrm{v} / \mathrm{v})$, flow rate, $0.8 \mathrm{~mL} / \mathrm{min}$, detection, OR. The identification of L-rhamnose in the $\mathrm{H}_{2} \mathrm{O}$ layer was carried out by comparing the retention time and polarity of the hydrolysis product with an authentic sample: $t_{\mathrm{R}}(\mathrm{min}) 7.8$ (L-rhamnose, negative polarity).

Cell Culture 3T3-L1 preadipocytes (American Type Culture Collection) were plated into 24-well plates and maintained in Dulbecco's modified Eagle's medium (DMEM) supplemented with $10 \%(\mathrm{v} / \mathrm{v})$ fetal calf serum (FCS) and $1 \%$ (v/v) penicillin-streptomycin at $37^{\circ} \mathrm{C}$ in a humidified $5 \% \mathrm{CO}_{2}$ incubator. To induce differentiation, $3 \mathrm{~d}$ post-confluent $3 \mathrm{~T} 3-\mathrm{L} 1$ preadipocytes (day 0 ) were stimulated by adipogenic agents (500 $\mu \mathrm{m}$ 3-isobutyl-1-methylxanthine, $1 \mu \mathrm{M}$ dexamethasone, and $10 \mu \mathrm{g} / \mathrm{mL}$ insulin) that were added to DMEM with $10 \%$ $(\mathrm{v} / \mathrm{v})$ fetal bovine serum (FBS) culture medium. After $3 \mathrm{~d}$, the medium were replaced with DMEM with $10 \%$ (v/v) FBS and $5 \mu \mathrm{g} / \mathrm{mL}$ insulin, and then replaced every $3 \mathrm{~d}$. The cells were harvested $8 \mathrm{~d}$ after the initiation of differentiation.

Cell Viability Assay Cell viability was assessed using 3-(4,5-dimethylthiazol-2-yl)-2,5-diphenyltetrazolium bromide (MTT). The cells $\left(1.0 \times 10^{5}\right.$ cells $\left./ \mathrm{mL}\right)$ were seeded in $96-$ well plates and incubated for $24 \mathrm{~h}$ at $5 \% \mathrm{CO}_{2}$ and $37^{\circ} \mathrm{C}$, and then treated with samples. After $24 \mathrm{~h}$ incubation, MTT solution $20 \mu \mathrm{L}(1 \mathrm{mg} / \mathrm{mL})$ was added into the cell culture, and further the cells were incubated at $37^{\circ} \mathrm{C}$ and $5 \% \mathrm{CO}_{2}$ for $4 \mathrm{~h}$. After removing the medium, the $\mathrm{MTT}$ formazan crystals were then dissolved with dimethyl sulfoxide (DMSO), and the absorbance in individual wells was determined at $570 \mathrm{~nm}$ using microplate reader and the background absorbance $(655 \mathrm{~nm})$ was subtracted. The test sample dissolved in DMSO was added.

TG Assay 3T3-L1 adipocytes were harvested 8d after the initiation of differentiation. The cells were washed with phosphate buffered saline (PBS) (-), scraped on ice in $500 \mu \mathrm{L}$ of sonication buffer $(25 \mathrm{~mm}$, Tris buffer and $1 \mathrm{~mm}$ ethylenediaminetetraacetic acid (EDTA), $\mathrm{pH}$ 7.5), and sonicated to homogenize the cell suspension. The total TG content in cells was determined using LabAssay ${ }^{\mathrm{TM}}$ Triglyceride (Wako Pure Chemical Industries, Ltd., Osaka, Japan). DNA concentration was determined using a DNA Quantity kit (Primary Cell Co., Ltd., Sapporo, Japan). TG concentration per $\mu \mathrm{g}$ of DNA in $3 \mathrm{~T} 3-\mathrm{L} 1$ cells was expressed as the ratio (\%) to the control value. The test sample dissolved in DMSO was added.

GPDH Assay 3T3-L1 adipocytes were harvested 8d after the initiation of differentiation. The cells were washed with
PBS (-), scraped on ice in $500 \mu \mathrm{L}$ of sonication buffer $(25 \mathrm{~mm}$ Tris buffer containing $1 \mathrm{~mm}$ EDTA, $\mathrm{pH} 7.5$ ), and sonicated to homogenize the cell suspension. GPDH activity was determined using a GPDH Assay kit (Primary Cell Co., Ltd., Sapporo, Japan). DNA concentration was determined using a DNA Quantity kit (Primary Cell Co., Ltd., Sapporo, Japan). GPDH activity per $\mu \mathrm{g}$ of DNA in 3T3-L1 cells was expressed as the ratio (\%) to the control value. The test sample dissolved in DMSO was added.

Glucose Uptake Assay 3T3-L1 adipocytes were harvested $8 \mathrm{~d}$ after the initiation of differentiation. After the differentiation, the medium was replaced with serum-free DMEM for $2 \mathrm{~h}$, and then cells were washed and incubated in KRH buffer (25 mM $N$-(2-hydroxyethyl)piperazine- $N$ '-2-ethanesulfonic acid (HEPES), $120 \mathrm{~mm} \mathrm{NaCl}, 5 \mathrm{~mm} \mathrm{KCl}, 1.2 \mathrm{~mm} \mathrm{KH}_{2} \mathrm{PO}_{4}, 1 \mathrm{~mm}$ $\mathrm{CaCl}_{2}, 1 \mathrm{mM} \mathrm{MgSO}_{4}, \mathrm{pH} 7.4$ ) containing insulin (200 nM) for $10 \mathrm{~min}$ at $37^{\circ} \mathrm{C}$. After exposed to insulin, cells were washed and treated with samples in KRH buffer for $15 \mathrm{~min}$. After incubation, [1- $\left.{ }^{3} \mathrm{H}\right]$-2-deoxy-D-glucose $(0.25 \mu \mathrm{Ci} / \mathrm{mL})$ was added, and incubation was continued for $10 \mathrm{~min}$. The cells were washed twice with ice-cold KRH buffer and then solubilized with $0.1 \%$ sodium dodecyl sulfate (SDS). The incorporated radioactivity was measured by liquid scintillation counting. Nonspecific uptake was determined in the presence of $20 \mu \mathrm{M}$ cytochalasin B and was subtracted from the total value. The test sample dissolved in DMSO was added.

Acknowledgments This work was supported in part by the Grant-in-Aid for Scientific Research from the Ministry of Education, Culture, Sports, Science and Technology (MEXT) of Japan (No. 20590016), and by the "High-Tech Research Center" Project for Private Universities: matching fund subsidy from 2007-2011.

\section{References}

1) Hu X., Zhang W. K., Zhu Q. S., “Zhong Hua Ben Cao," Vol. 4, ed. by Song L., Hu L., Zhang G., Shanghai Scientific \& Technical Publishers, Shanghai, 1999, p. 322.

2) Kang T. H., Jeong S. J., Kim N. Y., Higuchi R., Kim Y. C., J. Ethnopharmacol., 71, 321-323 (2000).

3) Li Z. P., Gao S., Hao C. S., Fan G. M., Chin. J. Chin. Mater. Med., 25, 103-104 (2000).

4) Li Z., Zhang M., Liu W., Mao Z., Nat. Prod. R\&D, 17, 585-587 (2005).

5) Jian K., Chang H. H., Zhe L., Zuo P. L., Chin. Chem. Lett., 18, 181-184 (2007).

6) Formiguera X., Cantón A., Best Pract. Res. Clin. Gastroenterol., 18, 1125-1146 (2004).

7) Kopelman P. G., Nature (London), 404, 635-643 (2000).

8) Furuyashiki T., Nagayasu H., Aoki Y., Bessho H., Hashimoto T., Kanazawa K., Ashida H., Biosci. Biotechnol. Biochem., 68, 23532359 (2004).

9) Wise L. S., Green H., J. Biol. Chem., 254, 273-275 (1979).

10) Saltiel A. R., Kahn C. R., Nature (London), 414, 799-806 (2001).

11) Bell R. M., Coleman R. A., Annu. Rev. Biochem., 49, 459-487 (1980).

12) Yao Y., Li X. B., Zhao W., Zeng Y. Y., Shen H., Xiang H., Xiao H., Lipids Health Dis., 9, 49-60 (2010).

13) Ohkura K., Mori M., Terada H., Makino S., Biosci. Biotechnol. Biochem., 59, 1485-1488 (1995).

14) Sul H. S., Smas C. M., Wang D., Chen L., Prog. Nucleic Acid Res. Mol. Biol., 60, 317-345 (1998).

15) Kubota H., Kojima-Yuasa A., Morii R., Huang X., Norikura T., Rho 
S., Matsui-Yuasa I., Am. J. Chin. Med., 37, 843-854 (2009).

16) Dell'Agli M., Bosisio E., Planta Med., 68, 76-79 (2002).

17) Ogawa T., Tabata H., Katsube T., Ohta Y., Yamasaki Y., Yamasaki M., Shiwaku K., Food Chem., 118, 239-244 (2010).

18) Kubota H., Morii R., Kojima-Yuasa A., Huang X., Yano Y., MatsuiYuasa I., Am. J. Chin. Med., 37, 597-608 (2009).

19) Ahn J. Y., Lee H. J., Kim S., Park J. H., Ha T., Biochem. Biophys. Res. Commun., 373, 545-549 (2008).

20) Iwashita K., Yamaki K., Tsushida T., Food Sci. Technol. Res., 7, 154-160 (2001).

21) Huang C., Zhang Y. B., Gong Z. W., Sheng X. Y., Li Z. M., Zhang W., Qin Y., Biochem. Biophys. Res. Commun., 348, 571-578 (2006).

22) Park S., Ahn Il. S., Kwon D. Y., Ko B. S., Jun W. K., Biosci. Biotechnol. Biochem., 72, 2815-2823 (2008).

23) Ejaz A., Wu D., Kwan P., Meydani M., J. Nutr., 139, 919-925 (2009).

24) Kasai R., Okihara M., Asakawa J., Mizutani K., Tanaka O., Tetrahedron, 35, 1427-1432 (1979).

25) Li Y. L., Li J., Wang N. L., Yao X. S., Molecules, 13, 1931-1941 (2008).

26) Lee H. J., Lee H. J., Lee E. O., Ko S. G., Bae H. S., Kim C. H., Ahn K. S., Lu J., Kim S. H., Cancer Lett., 270, 342-353 (2008).

27) Mattarei A., Biasutto L., Rastrelli F., Garbisa S., Marotta E., Zoratti M., Paradisi C., Molecules, 15, 4722-4736 (2010).

28) Matthes H. W. D., Luu B., Ourisson G., Phytochemistry, 19, $2643-$ 2650 (1980).

29) Awaad A. S., Maitland D. J., Soliman G. A., Bioorg. Med. Chem.
Lett., 16, 4624-4628 (2006).

30) Miyazawa M., Hisama M., Biosci. Biotechnol. Biochem., 67, $2091-$ 2099 (2003).

31) Zhang X. Q., Jiang Wei. W., Wang Y., Li Y. L., Ye W. C., Yao Xue Xиe Bao, 43, 281-283 (2008).

32) Jung M. J., Kang S. S., Jung H. A., Kim G. J., Choi J. S., Arch. Pharm. Res., 27, 593-599 (2004).

33) Terashima K., Kondo Y., Aqil M., Waziri M., Niwa M., Heterocycles, 50, 283-290 (1990).

34) Kim N. C., Graf T. N., Sparacino C. M., Wani M. C., Wall M. E., Org. Biomol. Chem., 1, 1684-1689 (2003).

35) Markham K., Ternai B., Tetrahedron, 32, 2607-2612 (1976)

36) Danieli B., Giardini A., Lesma G., Passarella D., Peretto B., Sacchetti A., Silvani A., Pratesi G., Zunino F. J., Org. Chem., 71, 2848-2853 (2006)

37) Tan J., Bednarek P., Liu J., Schneider B., Svatos A., Hahlbrock K., Phytochemistry, 65, 691-699 (2004).

38) Kwon H. C., Kim K. R., Zee S. D., Cho S. Y., Lee K. R., Arch. Pharm. Res., 27, 604-609 (2004).

39) Karl C., Müller G., Pedersen P., Phytochemistry, 15, 1084-1085 (1976).

40) Zou K., Tong W. Y., Liang H., Cui J. R., Tu G. Z., Zhao Y. Y., Zhang R. Y., Carbohydr. Res., 340, 1329-1334 (2005).

41) Spiegelman B. M., Hu E., Kim J. B., Brun R., Biochimie, 79, 111112 (1997).

42) Lane M. D., Lin F. T., MacDougald O. A., Vasseur-Cognet M., Int. J. Obes. Relat. Metab. Disord., 20, 91-96 (1996). 